\title{
The Modernisation of William Shakespeare's Hamlet: Identity and Gender in Iris Murdoch's The Black Prince
}

\author{
Alicia Muro Llorente \\ University of La Rioja, Spain
}

Copyright (c) 2018 by Alicia Muro Llorente. This text may be archived and redistributed both in electronic form and in hard copy, provided that the author and journal are properly cited and no fee is charged for access.

\begin{abstract}
This article reads Iris Murdoch's The Black Prince (1973) as a retelling of William Shakespeare's Hamlet (1603), paying special attention to the changes that the original play has gone through in order to render it more apt for a contemporary audience. Even if Murdoch also adapts the male hero, the most interesting changes she introduces are related to gender, since the female figures resembling Ophelia and Gertrude bear little resemblance to their Shakespearean counterparts. Gender is also linked to how the novel is written, especially regarding the narrator and his unreliability. Murdoch's views on women will thus be juxtaposed to those of her (male) narrator. The rest of Murdoch's characters are also crafted in Shakespearean fashion, given that almost all of them have a counterpart in the original play.
\end{abstract}

Key Words. Iris Murdoch, Shakespeare, Gender, Contemporary Literature, Identity, Intertextuality, Hypertextuality, Unreliability.

Resumen. The Black Prince (1973), de Iris Murdoch, será entendida en este artículo como una adaptación de la obra de William Shakespeare, Hamlet (1603), prestando especial atención a los cambios que ha sufrido la obra original para hacerla más adecuada al público contemporáneo. Aunque Murdoch también adapta el héroe masculino, los cambios más interesantes que introduce son en cuanto al género, puesto que las figuras femeninas semejantes a Ofelia o Gertrudis no tienen mucho en común con sus equivalentes originales. El género en la novela también tendrá que ver con la forma en la que está escrita, especialmente en cuanto al narrador y su no-fiabilidad. La perspectiva sobre género de Murdoch será así yuxtapuesta a la de su propio narrador o a la del autor original. El resto de los personajes en la novela también serán diseñados a la manera Shakespeariana, dado que casi todos los personajes encuentran sus equivalentes en la obra original.

Palabras clave. Iris Murdoch, Shakespeare, género, literatura contemporánea, identidad, intertextualidad, hipertextualidad, no-fiabilidad. 


\section{Introduction and Aims}

Iris Murdoch is considered to be an Anglo-Irish novelist and philosopher: she was born in Dublin in 1919 but moved to London before she was one year old. Even though she spent most of her life in the United Kingdom, Murdoch considered herself Irish. When asked who she was, she once claimed, "Well, I'm Irish anyway, that's something" (D'Alton, De Petris). Notwithstanding, some critics acknowledge that "she was an insider and an outsider at one and the same time" (D'Alton), alluding to the duality of her national identity, which is reflected in some of her literary works. Murdoch directly addresses Ireland in works such as "Something Special" (1957), The Unicorn (1963), and The Red and the Green (1965), besides other references to her homeland in works such as The Book and the Brotherhood (1987).

This article does not focus on Iris Murdoch's Irishness as reflected in her works but rather approaches Murdoch as one of those writers willing to accept the challenge of retelling and adapting a very well-known literary text for a contemporary audience. Given its plot and characters, her novel The Black Prince (1973) is bound to be read as a rewriting of William Shakespeare's Hamlet. ${ }^{1}$ Nonetheless, Murdoch was conscious of the difficulties and obstacles that these Shakespearean characters may encounter in her contemporary twentieth century, especially for her audience to relate to and identify with them, particularly with the female characters. She acknowledged the necessity of re-evaluating some of these recognizable characters and, consequently, not only reshaped the figure of the hero of the story but also the female figures.

The main aim of this article is to show the changes that some of Hamlet's characters underwent in order to render them more comprehensible to a contemporary audience, especially the female characters. The women in Shakespeare's play do not seem to have a significant role, since the centre of the stage is constantly given to Hamlet himself. In The Black Prince, even if Murdoch also assigns this spot to her male protagonist and anti-hero, the reader discovers at the end of the novel that the female characters were stronger and more powerful than he/she had initially thought. Apparently weak and passive characters like Gertrude or Ophelia would have had no place in the late twentieth or twenty-first century, so Iris Murdoch grapples with the issue of gender in her novel and depicts more appropriate versions of the female characters.

This comparison will allow us to juxtapose Shakespeare's and Murdoch's perspectives on women, taking into account their different historical circumstances. The Black Prince also contrasts Murdoch's views on women with those of her narrator, Bradley Pearson, as we will see. Murdoch's thoughts on the matter are mainly heard at the end of the novel, with the inclusion of the female voices, since what we hear throughout the whole novel is mostly Bradley Pearson's narrative and point of view.

As a consequence, another interesting aspect of this article will be the discussion of the figure of the unreliable narrator as a means to show the hero's selfishness and misogyny. Murdoch uses the narrator and literary style - seen in the insertion of the postscripts, for instance - to emphasise the deceiving nature of the male narrator and the revealing role played by the female characters.

In order to achieve these aims, I will start by analysing the roles of the characters of Hamlet. We will also attend to how the characters in The Black Prince compare to their counterparts in the Shakespearean play, paying attention to the multiplicity of roles performed by some characters in the novel. Finally, we will deal more specifically with the women in the novel, before discussing Bradley Pearson as an unreliable narrator. 


\section{The Hypotext: Women in Hamlet}

To begin with, there are only two female characters in Hamlet who actually have some importance for the plot: Queen Gertrude and Ophelia. Inevitably, these characters are also quite controversial for we do not really get to know them or understand their motivations, actions, or inner selves, we only learn about them through third parties. Nonetheless, from a simple approach to the play, these are rather weak and male-dominated characters, although this does not prevent critics from providing further interpretations that show their double nature and their true roles in the tragedy.

Gertrude has inspired much debate. As Queen of Denmark, she was allegedly happily married to Old King Hamlet, but does not hesitate for long when she gets a marriage proposition from her former brother-in-law, Claudius. One interpretation is that she, like him, is driven by ambition. After Old King Hamlet's death, she would be worthless, penniless, and without purpose - unless she married the new king. Claudius does not seem to care about her real reasons for marrying him.

However, in her revealing thesis, Gertrude's Role in Hamlet, Emily Graf argues that we have misunderstood Gertrude's motives. She claims that Gertrude is not the sensual character seen by audiences worldwide, but a mother whose first desire is to protect her son. Graf states that the queen is not able to defend herself against the accusations made against her by the ghost of her former husband and her son, both of whom Graf considers to be unreliable narrators. She claims that Hamlet is too driven by his emotions and thus unable to conceive a fair portrayal of his mother, and the audience should not take his words as the indisputable truth (Graf 23). Graf also argues that Gertrude could be accused of usurping Hamlet's inheritance and legal rights - the next in line to the throne of Denmark is no longer Prince Hamlet, but the first offspring resulting from Gertrude and Claudius's marriage (27). According to Graf, this is why Hamlet is so interested in his mother's sexuality - not because he is in love with her but because he feels his access to the throne to be in jeopardy.

Notwithstanding, there is another turn of the screw: that Gertrude might also be involved in Old King Hamlet's murder. ${ }^{2}$ In the play, Hamlet himself accuses his mother of being involved in the plot, although the queen dismisses the accusation and it is not mentioned again. Despite the Ghost's advice to Hamlet not to trouble his mother ("Taint not thy mind, nor let thy soul contrive / Against thy mother aught", 1.5.85-86), he confronts and torments her with his accusation (3.4.28-30):

HAMLET A bloody deed - almost as bad, good Mother,

As kill a king and marry with his brother.

GERTRUDE As kill a king!

The Ghost's words, together with Gertrude's astonishment and the fact that the allegation is not mentioned again, seem to suggest her innocence.

The other aspect of debate regarding Gertrude's actions is whether she knew about Claudius's plot to kill Hamlet at the end of the play, whether she knew that she was being poisoned. Several performances and interpretations of the play suggest that Gertrude was indeed aware of the treachery and drank from the cup to commit suicide after learning of her husband's wickedness, and/or to try to save her son. ${ }^{3}$ Graf argues that this is another instance where we can appreciate Gertrude's independence and ability to make her own decisions (44). When the king forbids her to drink from the poisoned cup ("Gertrude, do not drink", 5.2.264), she deliberately disobeys her husband's orders and takes control of her actions ("I will, my lord. I pray you pardon me", 5.2.265). 
Ophelia has also been the object of some research, but not as much as Gertrude. Ophelia seems to be a weaker character than the queen, with fewer lines (58 to Gertrude's 69). For the purposes of our analysis, Ophelia appears to have no other role in the play than the romantic interest of Prince Hamlet. She is surrounded by men, protected from her naïveté by her father Polonius and brother Laertes, whom she follows blindly. When they advise her against Hamlet, she accepts their truth, does not question their judgement, and starts behaving as they expect her to. Ophelia is treated as bait by the king and Polonius when they try to discern what is the matter with Hamlet, and Hamlet himself seems to treat her like an object in order to inspire jealousy in his mother (3.2.101-02). She even blames herself for Hamlet's madness, believing that his love for her is the real reason behind the prince's insanity (2.1.83-85):

$\begin{array}{ll}\text { POLONIUS } & \text { Mad for thy love? } \\ \text { OPHELIA } & \text { My lord, I do not know, } \\ & \text { But truly I do fear it. }\end{array}$

Ophelia is a victim of this patriarchal Renaissance society; she does not have thoughts of her own ("I think nothing, my lord", 3.2.108) and is not free to develop her actions or to choose whom she marries. Following this, it is understandable that, after her brother's escape to Paris, her father's death, and Hamlet's rejection, she finds herself at a loss - she has no one to tell her what to say or what to do, to direct her movements and to control her life, and consequently falls into madness and eventually commits suicide.

\section{The Hypertext: Identity and Gender in The Black Prince}

\subsection{Hamletian Characters in The Black Prince}

The first reference to Shakespeare's Hamlet in The Black Prince comes in its title, which inevitably reminds us of the Prince of Denmark in his mourning clothes. Bradley Pearson is thus linked not only to Hamlet but also to Edward of Woodstock, Prince of Wales, also known as "The Black Prince" due to the armour he wore in battle and his cruelty against his enemies. The Black Prince, like Hamlet and Pearson themselves, died too young to succeed, in every sense of the word.

Murdoch's retelling of Hamlet both forces and allows her to reshape the characters created by Shakespeare, introducing new aspects that turn them more accurately into contemporary figures. The vast majority of the characters in The Black Prince have a counterpart in Hamlet, but the most interesting aspect is that this encounter is not a one-to-one relationship, for one character from Murdoch's novel could be playing several roles from Hamlet, as is the case with Julian Baffin or her father, Arnold.

In fact, the role of Hamlet is played in The Black Prince by the two main characters, Bradley and Julian. Regarding the former, the most obvious reason is that the two characters are the protagonists of their stories and therefore occupy the centre of the stage. The rest of the characters thus revolve around Bradley, and have almost no story of their own without him. Bradley's madness and delay of his actions (such as the writing of his longed-for novel, for instance) seem to mirror some of the motifs encountered in the Prince of Denmark, and his envy of Baffin echoes Hamlet's anger at Claudius, as well as his possible jealousy at Claudius's accession to power and his marriage to Gertrude.

On the other hand, Julian also presents certain Hamletian characteristics - her dressing up as Hamlet being the most evident. She could also be described as suffering from an Electra complex, the female equivalent of the Oedipus complex, which is commonly attributed to Hamlet. Julian not only proclaims her love for her father in several scenes - "I think I never 
made it clear enough to you how much I love my father. (Perhaps he is the man of my life!)" (370) - but shows her taste for older men in her affair with Bradley. This also links her to the figure of Ophelia. As Julian says, "I loved [my father]. His violent death drove me nearly mad" (408), echoing the mourning Ophelia's drift towards madness and eventually suicide. Furthermore, Julian is protected by her parents, Arnold and Rachel, who strongly advise her not to become involved with Pearson - which links her to Ophelia once again, along with her shallowness and innocence. Although he claims to be hopelessly in love with Julian, Bradley emphasises her naïveté and even stupidity, her lack of education, and the shallowness of her remarks about Hamlet, for instance: "I saw her simplicity, her ignorance, her childish unkindness, her unpretty anxious little face. She was not beautiful or brilliantly clever" (208). Even Arnold and Rachel consider their daughter to be "a very unsophisticated child" (281), "a silly girl" (338). These observations also seem to position Julian alongside Ophelia, who is presented as an innocent and simple-minded, as has been stated above. Finally, Julian's relationship with Bradley is also a quite controversial and unusual for obvious reasons, just like Hamlet and Ophelia's relationship was uncommon due to the difference in social status (one being the Prince of Denmark and the other the daughter of a courtier). Julian's androgyny is what allows these multiple interpretations of the character as possessing several Hamletian identities.

Murdoch is not the first to have realised the potential of a female Hamlet, though. Throughout the centuries since its first performance, Hamlet has starred actresses who did not want to miss the chance to play the part every actor longs to play. In his inspiring study Women as Hamlet: Performance and Interpretation in Theatre, Film and Fiction, Tony Howard explores the consequences of a female Hamlet, understanding the role as the one that has "most inspired tragic actresses to challenge expectations and cross gender lines" (1). Howard also asserts that "what most female Hamlets have in common is that they are catalysts - inassimilable figures alien to the norms around them" (5). This statement could also be applied to Murdoch's Julian Baffin, a female Hamlet who challenges and confronts the norms that have been imposed upon her with her rejection to follow her parents' orders, for instance, as we shall see in following sections. The countless instances of female Hamlets show the universality of the role, the fact that his dilemmas are not unique to a particular gender. In The Black Prince, Iris Murdoch demonstrates this assertion in her creation of both a male and a female Hamlet in two different characters.

Priscilla is the other character who could be viewed as Ophelia-like, in her suicide, driven by the rejection of the people around her. As is implied in the case of Ophelia, Priscilla also kills herself, although we do not attend the actual suicide scene but we only hear about it from other characters, again echoing Ophelia: "she killed herself" (323). Priscilla too is believed to be mad, after the rejection of her husband Roger, who is happily expecting a child with his young mistress, and her brother Bradley, who does not really care about her state and leaves her in the care of underqualified hands.

Arnold and Rachel's couple has been interpreted as mirroring Claudius and Gertrude's for several reasons. Arnold resembles the king in the fact that he is an important figure with some power ("Are you the Arnold Baffin?", 32) married to a weak and submissive woman, though we will discover at the end of the novel that Rachel takes control of the situation in her own way - and it is debatable whether Gertrude did the same thing with the murder of Old Hamlet or her possible suicide. Furthermore, the first thing we learn about Arnold is that he is a violent man who is uncertain whether he has killed his wife, while the first thing the audience knows about Claudius is that he is a murderer.

The marriages in both works are also quite mysterious for the reader. To what extent are they real? We do not really learn much about Claudius and Gertrude's marriage, its causes, or motivations, just as we cannot really understand Arnold and Rachel's. It is implied that 
Arnold has been violent towards his wife on several occasions, to the extent that she states: "I've always been afraid of him" (40). So why is she still married to him? Is she, like Gertrude, just trying to preserve her status, or does she really love her husband? Is she, like Gertrude once again, just trying to protect her child? Arnold claims to be "a model husband" (46), asserts that "Rachel and I are very happily married" (45), but Rachel tries unsuccessfully to start an affair with Bradley and Arnold, meanwhile, finds himself in Christian's arms.

Their alleged "happy marriage" materializes in the second part of the novel, when Arnold and Rachel join forces to protect Julian from Bradley, to try to make them accept the impossibility of their relationship. Arnold resembles here a Polonius-like figure in his attempt to protect his daughter from a rotten and disastrous relationship. But Polonius can also be found in Francis, who plays a similar role as the comic relief.

\subsection{Rewriting the female characters}

The retelling of Hamlet that we encounter in The Black Prince not only must needs adapt the original play to a contemporary audience, but also re-evaluate the female characters. Even if the female characters in Shakespeare's play are not insignificant, their weakness and subordination sap much of their presence. The figure of the woman in the twentieth and twenty-first century, however, has evolved significantly, after such theoretical work as that of Simone de Beauvoir (The Second Sex, 1949), Betty Friedan (The Feminine Mystique, 1963), or Elaine Showalter ("Toward a Feminist Poetics", 1986), among others.

In basic terms, gender studies looks at the world from the perspective of gender (especially the female voice). In The Second Sex, Beauvoir writes: "The representation of the world as the world itself is the work of men; they describe it from a point of view that is their own and that they confound with the absolute truth" (196). Our two male heroes, Hamlet and Bradley Pearson, recount events from their own masculine point of view, leaving little room for the female voice. Nevertheless, the women in Murdoch's novel do not consent to this view and fight to offer their own perspectives, proving that they are worthy of as much consideration as the hero of the narrative himself.

It would not be going too far to read Bradley Pearson as a misogynist and prejudiced, a man whose views on women are probably highly influenced by his lack of education and, according to Francis, his alleged Oedipus complex. Along these lines, Bran Nicol claims that "Murdoch's first-person heroes are also, to varying degrees, misogynistic, bullying, ruthlessly selfish. ... The victims of their régime are most frequently women - unpredictable, fickle creatures who must be kept under control" (58). Thus, there is some complexity underneath the surface regarding gender in Murdoch's text, in the sense that we must bear in mind the existence of several perspectives on women. In point of fact, we not only get Bradley's perspective on gender, but also that of Iris Murdoch herself. Throughout the novel, from the Forewords to the end of Part Two, we encounter Pearson's story and therefore Pearson's point of view. The reader is asked to sympathize with the hero and, therefore, to reject the women in the tale (except for Julian, apparently), who are represented as emotionally needy and demanding, rather pathetic, and lacking in self-awareness. Bradley's generalizations about women are constantly being seen by the reader. For instance, he remarks that Rachel "turned to me with a grimacing smile such as women sometimes use, smiling through weariness and a self-indulgent desire to weep" (182), and he declares that he does not believe himself able to be "“friends' with a woman" (16).

With the end of the novel and the Postscripts, however, Murdoch introduces a twist: we have been reading the novel upside-down, Pearson's views on women are biased and prejudiced for several reasons, and the women in the tale are generally more powerful than we initially thought. Pearson (and, as a consequence, the reader, via Pearson's descriptions) 
understood Rachel, for instance, to be a frail and pathetic figure, whose need for a man in her life drives her from an abusive husband (whom she refuses to abandon) to another cruel and careless male figure. Murdoch presents her as a strong woman, taking the reins of her own life and cunningly taking action, exacting "such perfect revenge upon the two men in her life" (382). Along the same lines, Deborah Johnson argues that

The male narrator obviously de-centres the female point of view ... Murdoch is clearly aware of what she is doing and can both seriously and playfully exaggerate this decentring effect. Some of the reflections which she gives to her male narrators ... are almost Jacobean in their intense misogyny, their habit of generalising about "women".

With the creation of this kind of hero, Murdoch is clearly condemning these actions and thoughts by offering the centre of the stage to a prejudiced and narcissist man, allowing him to condemn himself, while opposing his perspective to those of the female characters, whose voices are finally heard at the end of the novel. Ming-ying $\mathrm{Xu}$ argues that "Murdoch empowers the women's voice in the unique narrative structure, reveals the reorientation of women's identity with more freedom of choice and reveals independence as the way to complete female individuality" (162). At the end of the novel, therefore, the female characters (with the exception of Priscilla) prove that they can do without men, and that they can establish their own identity. Hence, the reader witnesses their evolution from passivity to action. Xu claims along these lines that "their concern shifts from a clear understanding of themselves that they've already owned to an established female identity, circumscribed by social, economic, and personal restraints in the male-dominated society, which will weaken the subordination of women to men" (162). In the case of Priscilla, this subordination weakens but to a lesser degree than in the other characters.

Let us specifically analyse the situation of each of the female characters. Xu divides their condition in two categories: "[an] unfavourable one that women struggle to escape from and [a] favourable one that women are content with" (162). In general terms, I believe that all the female characters evolve from the first situation to the second, although Priscilla and Rachel are closer to the first scenario and Christian and even Julian, to a certain extent, seem to belong to the second one.

Priscilla finds herself in the first scenario and starts her struggle to get out of it by leaving her husband but, once she is alone and unattended, she no longer knows how or how to act or react and the only way out that she can find is suicide, driven by the lack of love in her life: "Priscilla died because nobody loved her" (Murdoch 2013: 366). One example of this fact is Bradley's lack of pity for his sister: "Poor Priscilla, I thought, poor poor Priscilla, with a pity for which I deserved no credit since I was simply feeling sorry for myself” (108). Thus, $\mathrm{Xu}$ understands the character of Bradley's younger sister as illustrating "the miserable consequences of women's overmuch dependence [sic] on men" (163), as the following quotation of Priscilla from the novel illustrates:

What did he say, did he want to see me, did he say I was awful? Oh my life has been such hell, but when I go back it won't be worse than now, it couldn't be. I'll try to be resigned and quiet. I'll try to do little things, I'll go to the cinema more. I won't shout and cry. If I'm quiet he won't hurt me, will he? Bradley, would you come with me to Bristol? I'd like you to explain to Roger. (Murdoch 2013: 223)

Priscilla implies Roger's violence towards her and her resignation, her desire to return to him, but only because she needs to be under the care of a man. Her last plea should be pointed out: 
Priscilla wants Bradley to be the one to explain things to Roger, proving her incapacity to take responsibility for her decisions or even the impossibility for her to amend them, showing her need once again for the help of a man.

In fact, when she later decides that she cannot live under her husband's shadow any longer, she rushes to her brother for help and, eventually, she ends up in Francis's care. Even though she is the first to take control of the relationship by deciding to leave Roger, he had been planning to do the same due to the child he was expecting with his young mistress. This seems to be the only moment in which she oversees her decisions, since even her abortion was decided and arranged by Roger and her family. When she eventually marries Roger, it is not because he loves her (or she him, for that matter) but because Priscilla and her mother make him believe that she was pregnant once again: "I married her because I couldn't bear to lose a second child. And there was no child" (103). Thus, the shallow Priscilla achieved what she wanted: to be married to a wealthy husband and become a trophy wife, free of expectations that she do anything else for the rest of her life - she is left "fruitless and bootless" (133). In fact, her only consolation and motivation in life are her jewellery and other material objects that she has regrettably left behind in her escape.

The rest of the characters who find themselves under patriarchal control are able to escape that situation, with the exception of Priscilla. Xu claims that the lack of positive male figures in Priscilla's life "helps women realize the impossibility to hang everything on men as ... their mothers did in the past" (164). Therefore, Murdoch's female readership seems to be able to draw some wisdom from Priscilla's experience regarding what to avoid, and on how to react from characters like Rachel.

Rachel is another character living under male oppression and willing to escape from it. The proper story begins with Arnold's uncertainty as to whether he has killed Rachel (ironically, it will end the other way round: the reader will be unsure as to whether Rachel has killed her husband or not), and it is implied that it is not the first time that her husband has been violent with her. She acknowledges her position as the subjugated housewife as follows:

He has taken my whole life from me ... He has just blocked me off from everything. I can't work, I can't think, I can't be, because of him ... I've never been myself or lived my own life at all ... He has taken my life from me and spoilt it, breaking every little piece of it, like the breaking of every bone in one's body, every little thing ruined and spoilt and taken away ... He wouldn't let me take a job. I obeyed him, I've always obeyed him. I haven't any private things. He owns the world. It's all his, his, his. (Murdoch 2013: 40-41)

Rachel personifies the dominated woman, the woman who is forced to stay at home, taking care of the children instead of going to work, which is the preserve of men. I agree with Xu that "Rachel's remarks express the general plight of the housewife, who are [sic] confined to the household for the destruction of their female identity by the male supremacy that Rachel complains [sic]" (166). She speaks on behalf of all women when she states that "a married woman has no dignity, no thoughts which really stand up separately. She's a subdivision of her husband's mind, and he can release misery into her consciousness whenever he pleases ... I have no belief of my own" (Murdoch 2013: 176). Rachel is thus also speaking on behalf of Priscilla, for instance, although Priscilla is not conscious of her situation as a subjugated woman.

However, this realization is not what triggers Rachel's final revenge on her abusive husband, rather it is her discovery of his affair with Bradley's ex-wife. It is not his abuse that makes her want to leave him and even murder him, but his rejection, his betrayal. Arnold appears rather indifferent to Rachel's attempt to have an affair with Bradley, an infidelity 
linked to Bradley's rejection and betrayal too, since he is also unwilling to have a relationship with her and, contrariwise, starts an affair with Rachel's own daughter, Julian. As Xu points out in this regard, "Rachel becomes completely enraged by Bradley's elopement with her daughter Julian and Arnold's letter to Bradley confessing his love to Christian" (166) - in a matter of days she has been rejected by both her husband and the man she believed to be her lover. Finally, it should be pointed out that her final revenge does not bring her the happiness she expected but rather loneliness and a broken family caused by the death of her husband and the flight of her daughter, who cuts all ties with her (Xu 166).

Julian starts the rebellion against the imposed status quo earlier than her mother. According to $\mathrm{Xu}$, Julian is characterized "as a young woman who sets up her goal of life [sic], reorients her life plan and arranges her life accordingly in the light of her own wishes rather than the social or the parental expectations for a woman" (162). Firstly, she rejects the popular expectations of women to take care of their feminine image by dressing and behaving like a man. She also establishes her independence in denying her role as a dutiful daughter by running away with Bradley, explicitly against her parents' wishes, after she has been caged in her room. Bradley goes to the rescue of the damsel in distress, but his failure proves her ability to escape by her own means - just as, when Arnold goes to Patara to save his daughter from the claws of the terrible monster, she rejects his help and throws him out of the house, going home by herself afterwards. Xu understands this decision as Julian's "self-control and dispassion" in her promise to go back home the following day because "she likes to make the decision herself" (163). Thus, Julian is constantly rejecting the identity that has been imposed upon her - that of the defenceless princess in need of a hero.

Finally, the reader does not really witness Christian's evolution, but rather the image of Christian we get implies that she had already gone through a revealing transformation. Even though Bradley's narration does not clarify the end of his marriage to Christian, she claims in her postscript that "the trouble with our marriage was that I was young and wanted more fun and happiness than Bradley was able to give me" (Murdoch 2013: 393), implying that it was her who had decided to put an end to the relationship. She then married a wealthy American whose death left her a well-off widow who returned to London not because she was still in love with Bradley, as he claims, but because "I was curious to see what had happened to him in the between time" (394).

Bradley, once again, seems to be quite possessive towards Christian, since he controls her relationships with the rest of the characters by not allowing his own friends to meet her. He also complains every time someone calls her "Chris", which she understands as a sign of ownership:

'Steady on, Bradley, maybe Chris is right'.

'And don't call her Chris'.

'You can't have it both ways, Brad, disown me and -'. (113)

Christian implies here that naming equals owning, that his imposition of her full name establishes his ownership of her.

In The Black Prince we come across two different female positions and two different reactions against the imposed subjugation of womankind: rebellion or resignation. The reader can extract a lesson from the women in the story - how to react and what to avoid. Murdoch's main achievement with the novel is the juxtaposition of Bradley's manly, prejudiced, and oldfashioned perspective on life and gender with the women's perspective and rejection of the male-dominated world they find themselves trapped in. 


\subsection{Decentring the Male Character: Bradley as Unreliable Narrator}

As mentioned above, the narrator of The Black Prince could be classified as unreliable, which helps the author unmask him at the end of the novel as prejudiced and selfish. Wayne C. Booth coined the term: "I have called a narrator reliable when he speaks for or acts in accordance with the norms of the work (which is to say, the implied author's norms), unreliable when he does not" (158-59; emphasis in the original). Different subcategories apply to this kind of narrator, since we can encounter consciously unreliable storytellers or unconsciously unreliable ones. In the case of The Black Prince, Murdoch's Bradley Pearson is consciously unreliable, since he deceives the audience for a purpose.

Iris Murdoch compares the narrator's views on women and her own. With this antihero, Murdoch is able to explore the female characters more seriously, since the unreliability of Bradley Pearson is confronted with the incursion of the postscripts. Throughout the novel, Bradley prevents female voices from being heard, but at the very end Murdoch allows them to shout out their own side of the story.

In a novel such as this one, the writing style is very closely linked to the construction of the hero's identity. Thus, The Black Prince is a metafictional novel, ${ }^{4}$ loaded with intertextual references not only to Hamlet but also to other classical texts, such as Dickens's Our Mutual Friend or Cervantes's Don Quixote, among others. ${ }^{5}$ Bradley Pearson, however, is not only the author and narrator of the novel-within-the-novel but also its protagonist, since we could consider his novel as an apologia, as he himself calls it, or an autobiography. After all, "The Black Prince" is Pearson's story as recalled from prison, his attempt to explain why he has ended up there. The author/hero interrupts the narration to address his audience on several occasions ("Perhaps at this point in my story, my dear friend, I may be allowed to pause and speak to you directly", 79), and he keeps reminding us of the time changes that we undergo throughout the text, such as the fact that he is writing his story from a different space and time than when the actions actually took place.

As noted, the hero of the novel is also the narrator, and quite a peculiar one. Most of the beauty of The Black Prince, as is usual with this kind of novel, resides in the fact that at the end we realize we have been dealing with an unreliable first-person narrator. Although Bradley could have chosen a third-person external, and therefore more objective, narrator to tell his story (achieving his purpose in a more straightforward manner), he decides to star as the hero of his tale, probably following his desire to be in the spotlight. As a consequence, the reader knows that the narrative is going to be completely subjective, biased by the fact that it is an apologia, that the hero/author wants to be liked and forgiven by the audience. Even if Bradley claims that he has been an "honest narrator" (207), we learn at the end of the novel that this is not the case. With statements such as "I ... will go on as faithfully as I can to recount what happened next" (210; my emphasis), we can appreciate his intention to be truthful, but he is also implying that he cannot guarantee his own honesty - thus, if he does not perform as the reader would expect him to, he should not be blamed. In order to appear honest, he includes in his narrative letters that he sends and receives, which convey the text a false sense of authenticity and reliability. These letters are the only moments, within the actual novel, in which we hear from the other characters until the arrival of the postscripts, which contradict what we have learnt from the letters. The four postscripts dismantle everything Bradley has been recounting to his reader. Every truth that Bradley defends in "The Black Prince" is pulled apart - his relationships with the other characters, his feelings, and even his actions. 
We must also take into account that Bradley is recounting these events from prison, where he finds himself after Rachel blames him for the murder of her husband. Even if I agree with statements such as Rebecca Moden's ("Murdoch relies on the convention of the wiser Bradley who comments on the narrative of the earlier, blinded Bradley", 10), Pearson's account of events is not going to be objective or necessarily truthful, given his resentment against some of the characters. The passing of time and the nature of memory are also going to influence his perception of past events, and therefore his narration. All this indicates the unreliability of Bradley as a narrator, which is finally questioned by the postscripts.

At the end of the novel, therefore, the reader is forced to reinterpret everything he/she has read up to this point, to analyse the novel from a different perspective and with a different view of reality and truth. This is especially true in terms of characterization. We read the story from one angle (Bradley's) but, at the end of the novel, we are given the picture from every possible perspective. Why would the editor do this? Why would Loxias, who continuously claims to be Bradley's dearest (and probably only) friend, betray him this way? As he states, his intention with "The Black Prince" was "to vindicate the honour of my dear friend, to clear him, briefly, of the charge of murder" (413). With the postscripts, nonetheless, what he achieves is to arouse a severe suspicion in the reader, who becomes reluctant to believe anything read so far. Why should we believe Bradley's (and Loxias's) account of the final events and not Rachel's? Who can we trust in this novel? The editor asserts in his final postscript that "the reader will recognize the voice of truth when he hears it. If he does not, so much the worse for him" (412). Is the reader actually able to "recognize the voice of truth"? Murdoch, unlike Loxias, asks the audience to sympathize with the rest of the characters instead of the hero, showing his deceptive nature. After all, Murdoch had been warning us through the whole novel, in all the instances in which we have seen Bradley to be capable of lying and being untruthful, even in the most important of situations - in one way or another, he has lied to every single character of the novel. Thus, we should not be surprised by his lying to the reader - in fact, we should be expecting it.

Taking everything into account, the different levels of narration appear as a device to shape the identity of the hero and to pose questions regarding his role as author and narrator. As a metafictional novel, its self-reflective nature surrounds the plot and leaves the reader unsatisfied as to where the truth resides and to what extent we are willing to believe everything we are told. The editor, finally, does not help clarify the situation, but rather adds to the confusion.

\section{Conclusion}

As this article has aimed to prove, the aspect that has undergone the broadest changes in The Black Prince's adaptation of Shakespeare is that of the characters. Murdoch's novel understands characters in Hamletian terms, in the sense that we can encounter figures resembling Gertrude, Ophelia, or even Polonius. Opaque in Shakespeare, Murdoch proposes a perspective in which the Gertrude-like figure has taken the reins of her life and plays with the Claudius-like figure at will.

Therefore, there is not only a need for the adaptation and modernisation of the hero to a contemporary ambience, but also the roles played by the female characters. Shakespeare's perspectives on gender have been widely analysed and discussed, and Murdoch does not want to miss the debate. She introduces powerful female figures who are juxtaposed to their counterparts in Hamlet. Thus, she is not presenting the female characters at the centre of the stage, but rather she is analysing female perspectives through the eyes of the male protagonist. Murdoch is thus capable of interiorising extreme perspectives which are completely different 
from her own, understanding the male point of view perfectly well and exploring female characters through the male gaze.

In conclusion, the adaptation of Hamlet in The Black Prince not only addresses contemporary concerns regarding identity and gender, but also shows the need to find a more truthful protagonist and to re-evaluate his relationship with the female characters. The women in this story are subtly given the centre of the stage, to some extent, and are thus allowed to challenge the male protagonist's perspective on life. Even if the novel follows the (anti)hero's quest for his identity, instead of fully establishing it, the ending reveals that the ultimate focus was on the female figures.

\section{Notes}

\footnotetext{
${ }^{1}$ Taking into consideration the close relationship between the novel and the Shakespearean play, it seems more accurate to talk about hypertextuality than intertextuality, a term coined by Julia Kristeva. Genette broadened Kristeva's term to refer to "any relationship uniting a text B (... hypertext) to an earlier text A (... hypotext), upon which it is grafted in a manner that is not that of commentary" (5). Hence, hypertextuality encompasses Murdoch's whole narrative technique in her retelling of Shakespeare's play, which may be read as the hypotext for Murdoch's novel.

${ }^{2}$ This is the interpretation adopted by some contemporary writers in their adaptations of the play, such as Ian McEwan in Nutshell (2016) or Margaret Atwood in her short story "Gertrude Talks Back" (1992), among others.

${ }^{3}$ For instance, in the 2009 adaptation of the Royal Shakespeare Company, starring David Tennant, Penny Downie plays Gertrude as consciously drinking from the poisoned cup, perhaps for the aforementioned reasons.

4 Patricia Waugh defines "metafiction" as "a term given to fictional writing which self-consciously and systematically draws attention to its status as an artefact in order to pose questions about the relationship between fiction and reality" (2). In The Black Prince, the reader is constantly being reminded of the fictionality of the text; even from the very beginning of the novel we acknowledge that we are indeed reading a novel written by the protagonist of Murdoch's work, entitled "The Black Prince: A Celebration of Love", as we learn from the Editor. Other references to the process of writing reinforce this idea.

${ }^{5}$ Intertextuality, as understood by Julia Kristeva, refers here to the common set of references to other texts that we can find within a given text.
}

\section{Works Cited}

Atwood, Margaret. “Gertrude Talks Back”. Good Bones. Toronto: Coach House Press, 1992. $15-18$.

Beauvoir, Simone de. The Second Sex. London: Vintage, 1989.

Booth, Wayne C. The Rhetoric of Fiction. London: Penguin Books, 1991 (1961).

Cervantes, Miguel de. Don Quixote. Trans. Edith Grossman. London: Vintage Classics, 2005 (1605).

D’Alton, Ian. "In Praise of Iris Murdoch”. The Irish Times. 3 June 2015. 19 February 2018. https://www.irishtimes.com/culture/books/in-praise-of-iris-murdoch-by-ian-d-alton1.2235736 .

De Petris, Carla. “'Who am I? Well, I'm Irish anyway, that's something.' Iris Murdoch and Ireland". Studi irlandesi. A Journal of Irish Studies 6 (2016): 259-70.

Dickens, Charles. Our Mutual Friend. London: Wordsworth Classics, 1997 (1865).

Friedan, Betty. The Feminine Mystique. London: Penguin Classics, 2010 (1963).

Genette, Gerard. Palimpsests: Literature in the Second Degree. Lincoln, NE: University of Nebraska Press, 1997.

Graf, Emily. Gertrude's Role in Hamlet. Senior honours thesis. Eastern Michigan University, 2013.

Hamlet. Dir. Gregory Doran. [DVD] UK: BBC, Royal Shakespeare Company, 2009. 
Howard, Tony. Women as Hamlet: Performance and Interpretation in Theatre, Film and Fiction. Cambridge: Cambridge University Press, 2007.

Johnson, Deborah. Iris Murdoch. Brighton: The Harvester Press, 1987.

Kristeva, Julia. Desire in Language: A Semiotic Approach to Language and Art. New York: Columbia University Press, 1980.

McEwan, Ian. Nutshell. London: Jonathan Cape, 2016.

Moden, Rebecca. Illusion and Reality in the Fiction of Iris Murdoch: A Study of The Black Prince, The Sea, The Sea and The Good Apprentice. MPhil thesis. University of Birmingham, 2011.

Murdoch, Iris. The Book and the Brotherhood. London: Penguin Books, 1989.

- Something Special: A Story. London: W. W. Norton, 2000 (1957).

- The Unicorn. London: Vintage, 2001 (1963).

- The Red and the Green. London: Vintage, 2002 (1965).

. The Black Prince. London: Vintage, 2013 (1973).

Nicol, Bran. Iris Murdoch: The Retrospective Fiction. London: Macmillan Press, 1999.

Shakespeare, William. Hamlet. New York: Norton Critical Editions, 2011 (1603).

Showalter, Elaine. "Toward a Feminist Poetics". The New Feminist Criticism: Essays on Women, Literature and Theory. Ed. Elaine Showalter. London: Virago, 1986. 125-43.

Waugh, Patricia. Metafiction: The Theory and Practice of Self-Conscious Fiction. London: Methuen, 1984.

$\mathrm{Xu}$, Ming-ying. "The Establishment of Female Identity in The Black Prince". American International Journal of Social Science 3.3 (2014): 161-67.

Alicia Muro (Logroño, 1994) is a PhD student at the University of La Rioja, where she also took her undergraduate degree in English and a Master's Degree of Advanced Studies in the Humanities. She also had the opportunity of studying one year abroad in the National University of Ireland (Galway), where her interest for Irish culture and literature began. Her current $\mathrm{PhD}$ research is focused on the figure of the unreliable narrator in contemporary literature and its relationship with other topics such as memory, trauma, or guilt.

alicia.muro@alum.unirioja.es 